\title{
Pengaruh Penambahan Puree Daun Kelor ( Moringa oleifera) Terhadap Karakteristik Siomay Ayam
}

\section{Effect Of Adding Moringa Leaf Puree (Moringa oleifera) On The Characteristics Of Chicken Dumpling}

\author{
Putu Yumiko Murdiasa ${ }^{1}$, I Putu Suparthana ${ }^{1^{*}}$, Putu Timur Ina ${ }^{1}$ \\ Program Studi Teknologi Pangan, Fakultas Teknologi Pertanian, \\ Universitas Udayana, Kampus Bukit Jimbaran, Badung-Bali \\ Penulis korespondensi: IP.Suparthana, Email: putusuparthana@unud.ac.id
}

\begin{abstract}
Dumpling is one type of dimsum, wich is a food that originates from China.The purpose of adding moringa leaf puree to chicken dumplings is to add antioxidant, vitamin $\mathrm{C}$ and crude fiber content to dumplings. The purpose of this research is to obtain the concentration of the addition of the appropriate Moringa leaf puree to produce chicken dumplings with the best characteristics. This research design used was a Completely Randomized Design with adding Moringa leaf puree wich consist by 5 levels: $0 \%, 10 \%$, $20 \%, 30 \%$ and $40 \%$. Each treatment was repaeat 3 times so that obtained 15 experimental units. The data obtained were analyzed by variance and if the treatment had significant effect followed by Duncan multiple range test. The results showed that the effect of adding moringa leaf puree had a significant effect $(\mathrm{P}<0,01)$ on moisture content, crude fiber, vitamin $\mathrm{C}$, antioxidant activity, significant effect on ash content, color hedonic test, texture scoring test. The best treatment in this research was the addition of $40 \%$ moringa leaf puree with the following characteristics: $58.95 \%$ moisture content, $1.97 \%$ ash content, $2.18 \%$ crude fiber content, vitamin C $0.22 \mathrm{mg} / \mathrm{g}$ and antioxidant activity $38.30 \%$ with IC50 value $12342.28 \mathrm{ppm}$, the texture are very chewy and rather liked, the, the aroma, the taste and overall reception are rather liked.
\end{abstract}

Keywords: chicken dumpling, moringa leaf, antioxidants

\section{PENDAHULUAN}

Dimsum merupakan makanan yang berasal dari Tiongkok yang terbuat dari daging, udang atau ikan yang dibungkus dengan kulit pangsit kemudian dikukus (Novelia et al., 2016). Siomay adalah salah satu jenis dimsum yang banyak dijual baik di restoran Tionghoa maupun pedagang kaki lima. Siomay dalam bahasa Mandarin disebut shaomai merupakan daging cincang yang dibungkus kulit yang tipis dari tepung terigu dan dimasak dengan cara dikukus. Siomay pada awalnya berbahan dasar daging babi, namun seiring perkembangannya kini siomay banyak dikembangkan dengan bahan dasar daging ayam, ikan maupun udang.

Kandungan gizi utama pada siomay yaitu protein yang berasal dari daging ayam, udang maupun ikan, namun siomay rendah akan kandungan antioksidan, vitamin dan serat karena bahan dasar siomay menggunakan produk hewani dan sedikit bahan dari produk nabati. Salah satu cara untuk meningkatkan kandungan antioksidan, vitamin dan serat pada siomay adalah dengan menambahkan bahan nabati 
yang kaya akan kandungan tersebut seperti daun kelor.

Daun kelor merupakan salah satu bagian dari tanaman kelor yang telah banyak diteliti kandungan gizi dan kegunaannya. Daun kelor sangat kaya akan nutrisi, diantaranya kalsium, besi, protein, vitamin A, vitamin B dan vitamin C (Misra et al., 2014). Salah satu kandungan yang paling menonjol pada kelor adalah antioksidan, terutama pada bagian daunnya, adapun antioksidan yang terdapat pada daun kelor yaitu tanin, steroid, triterpenoid, flavonoid, saponin, antarquinon, dan alkaloid (Kasolo et al., 2010). Berdasarkan penelitian Verma et al. (2009) bahwa daun kelor mengandung fenol yang dikenal sebagai penangkal senyawa radikal bebas. Kandungan fenol dalam daun kelor segar sebesar 3,40\% sedangkan pada daun kelor yang telah diekstrak sebesar 1,60\% (Foild et al., 2007). Kandungan Vitamin $\mathrm{C}$ daun kelor 7 kali buah jeruk, Vitamin A 4 kali wortel, kalsium setara 4 gelas susu, potassium 3 kali pisang dan protein setara 2 yoghurt. Oleh karena itu kelor berpotensi sebagai fortivikan yang ditambahkan dalam pangan. Gopalakrishnan et al. (2016) menyebutkan kandungan daun kelor segar per $100 \mathrm{~g}$ adalah sebagai berikut: Protein $6.7 \mathrm{~g}$, karbohidrat $12.5 \mathrm{~g}$, serat $0.9 \mathrm{~g}$, vitamin B1 $0.06 \mathrm{mg}$, vitamin B2 $0.05 \mathrm{mg}$, vitamin B3 $0.8 \mathrm{mg}$, vitamin C $220 \mathrm{mg}$, vitamin E $448 \mathrm{mg}$, kalsium $440 \mathrm{mg}$, magnesium $42 \mathrm{mg}$, fosfor $70 \mathrm{mg}$ dan potassium sebesar $259 \mathrm{mg}$.
Daun kelor dapat diolah menjadi puree untuk digunakan sebagai bahan tambahan atau pensubtitusi dalam pembuatan produk. Pengolahan daun kelor menjadi puree dapat mempertahankan kandungan gizi pada daun kelor karena tidak mengalami proses pemanasan dan pengeringan sehingga kandungan gizinya tidak rusak. Puree daun kelor dibuat dengan cara memblender daun kelor segar hingga halus dan diberi sedikit air. Penambahan puree daun kelor pada siomay ayam bertujuan untuk menambah antioksidan, vitamin dan serat.

Berdasarkan teori yang telah dikaji, penambahan puree daun kelor pada siomay ayam dapat meningkatkan kandungan gizi siomay terutama Vitamin $\mathrm{C}$ dan aktivitas antioksidan. Namun saat ini belum diketahui secara pasti pengaruh penambahan puree daun kelor terhadap karakteristik siomay ayam, serta jumlah penambahan puree daun kelor yang tepat untuk menghasilkan siomay ayam dengan karakteristik terbaik. Adapun karakteristik siomay ayam yang diamati meliputi kadar air, kadar abu, kadar serat kasar, Vitamin C, aktivitas antioksidan, tekstur, warna, aroma, rasa dan penerimaan keseluruhan. Berdasarkan kandungan gizi pada kelor maka dapat diketahui penambahan daun kelor pada siomay ayam dapat meningkatkan nilai gizi siomay, namun penambahan puree daun kelor yang terlalu banyak tentunya juga dapat mempengaruhi mutu sensoris dari siomay. 
Maka dari itu, penelitian penambahan puree daun kelor terhadap karakteristik siomay ayam perlu dilakukan.

\section{METODE PENELITIAN}

\section{Tempat dan Waktu}

Penelitian ini dilakukan di Laboratorium Analisis Pangan, Laboratorium Pengolahan Pangan dan Laboratorium Rekayasa Proses dan Pengendalian Mutu, Fakultas Teknologi Pertanian, Universitas Udayana Gedung Agrokomplek, Jalan PB. Sudirman, Denpasar, Bali. Penelitian ini dilakukan dari bulan Januari sampai dengan bulan Maret 2020.

\section{Bahan dan Alat}

Bahan yang digunakan pada penelitian ini dibagi menjadi tiga yaitu bahan baku, bahan tambahan dan bahan kimia. Bahan baku untuk pembuatan siomay terdiri dari daging ayam broiler bagian dada tanpa tulang dan kulit yang diperoleh dari Pasar Badung, Denpasar dan daun kelor yang dipetik dari pucuk hingga 3 sub ranting dibawahnya yang masih hijau, tidak keriput, dan tidak dimakan ulat yang dipetik langsung dari Desa Sibanggede, Kecamatan Abiansemal, Kabupaten Badung. Bahan tambahan yaitu tapioka (Rose Brand), telur ayam, kulit pangsit (Fresh Indo), bawang merah, bawang putih, garam, gula dan merica bubuk diperoleh di Pasar Badung, Denpasar. Bahan kimia yang digunakan dalam melakukan analisis yaitu aquades, methanol (Merck), $\mathrm{K}_{2} \mathrm{SO}_{4}$ (Sigma), $\mathrm{NaOH}$ (Merck), $\mathrm{H}_{2} \mathrm{SO}_{4}$ (Merck), $\mathrm{HCl}$ (Merck), 1,1difenil-2-pikrilhidrazil (DPPH) (Sigma).

Alat-alat yang digunakan dalam penelitian ini dibagi menjadi dua yaitu alat untuk membuat siomay dan alat untuk analisis karakteristik siomay. Alat yang digunakan untuk pembuatan siomay yaitu timbangan digital (Tanita), gelas ukur (Pyrex), baskom, pisau, sendok, blender (Miyako), kompor gas (Rinnai), panci pengukus, mangkuk. Alat yang digunakan untuk analisis karakteristik siomay yaitu lumpang, kertas saring, kertas whatman 42, corong, eksikator, oven (Memmert), timbangan analitik a(Shimadzu), aluminium foil (Klin Pak), pinset, pipet tetes, pipet volume (Pyrex), kompor listrik, labu erlenmeyer (Pyrex), gelas beaker (Pyrex), gelas ukur (Pyrex), pompa karet, labu takar (Pyrex), botol timbangan, tabung reaksi (Pyrex), water bath (Thermology), spektrofotometer (Thermo), perangkat komputer dan lembar quisioner.

\section{Rancangan Penelitian}

Rancangan percobaan yang digunakan dalam penelitian ini adalah Rancangan Acak Lengkap (RAL) dengan perlakuan penambahan puree daun kelor terdiri dari 5 perlakuan, yaitu: $\mathrm{P} 0=$ Puree daun kelor 0\%; P1 = Puree daun kelor 10\%; $\mathrm{P} 2=$ Puree daun kelor 20\%; P3 = Puree daun kelor 30\%; P4 = Puree daun kelor 40\%. Masing-masing perlakuan diulang sebanyak 3 kali sehingga diperoleh 15 unit percobaan. 
Data yang diperoleh dari hasil penelitian dianalisis dengan sidik ragam dan apabila perlakuan berpengaruh terhadap variabel maka akan dilanjutkan dengan Duncan Multiple Range Test (Gomez dan Gomez, 1995).

\section{Variabel yang Diamati}

Variabel yang diamati dalam penelitian ini adalah kadar air dengan metode pengeringan (Sudarmadji et.al., 1997), kadar abu dengan metode pengabuan langsung (AOAC, 1995), penentuan kadar serat kasar dengan metode hidrolisis asam basa (Sudarmadji dkk., 1997), analisis kadar Vitamin C dengan metode spektrofotometri (Vuong, et al., 2014), aktivitas antioksidan dengan metode DPPH (Sompong et al., 2011) dan evaluasi sensoris diuji dengan uji hedonik (warna, rasa, tekstur, aroma, dan penerimaaan keseluruhan) serta uji skoring terhadap tekstur (Soekarto, 1985).

\section{Pelaksanaan Penelitian}

Tahap pelaksanaan penelitian meliputi beberapa tahap yaitu :

\section{Pembuatan Puree Daun Kelor}

Proses pembuatan puree dimulai dengan memisahkan daun dari ranting, disortasi untuk menghilangkan bahan asing, daun kelor dicuci menggunakan air mengalir, dilanjutkan dengan menghaluskan daun kelor menggunakan blender dengan mencampurkan air yaitu $10 \mathrm{ml}$ untuk 100 gram daun kelor (Asih et al., 2017).

\section{Pembuatan Siomay Ayam}

Adapun tahapan pembuatan siomay yaitu daging ayam dicuci lalu digiling, semua bahan ditimbang dan disiapkan sesuai dengan formula pada Tabel 1, kemudian semua bahan utama dicampur sehingga membentuk adonan siomay, dibungkus dengan kulit pangsit lalu dikukus selama 20 menit dengan suhu $70^{\circ} \mathrm{C}$.

Tabel 1. Formula siomay ayam dengan penambahan daun kelor

\begin{tabular}{|c|c|c|c|c|c|c|}
\hline \multirow[t]{2}{*}{ No. } & \multirow[t]{2}{*}{ Komposisi } & \multicolumn{5}{|c|}{ Perlakuan } \\
\hline & & $\mathrm{P} 0$ & $\mathrm{P} 1$ & $\mathrm{P} 2$ & P3 & $\mathrm{P} 4$ \\
\hline 1. & Daging Ayam (\%) & 100 & 100 & 100 & 100 & 100 \\
\hline 2. & Puree Daun Kelor (\%) & 0 & 10 & 20 & 30 & 40 \\
\hline 3. & Tapioka (\%) & 10 & 10 & 10 & 10 & 10 \\
\hline 4. & Putih Telur (\%) & 15 & 15 & 15 & 15 & 15 \\
\hline 5. & Garam (\%) & 2 & 2 & 2 & 2 & 2 \\
\hline 6. & Gula $(\%)$ & 2 & 2 & 2 & 2 & 2 \\
\hline 7. & Bawang Putih (\%) & 10 & 10 & 10 & 10 & 10 \\
\hline 8. & Bawang Merah (\%) & 5 & 5 & 5 & 5 & 5 \\
\hline 9. & Merica Bubuk (\%) & 1 & 1 & 1 & 1 & 1 \\
\hline
\end{tabular}

Keterangan: Persentase di atas berdasarkan berat daging ayam $100 \mathrm{~g}$.

Sumber: Ariyani (2015) yang dimodifikasi 


\section{HASIL DAN PEMBAHASAN}

\section{Analisis Bahan Baku}

Hasil analisis kadar air, kadar abu, kadar serat kasar, vitamin $\mathrm{C}$ dan aktivitas antioksidan puree daun kelor dapat dilihat pada Tabel 2. Hasil analisis puree daun kelor pada Tabel 2 selaras dengan hasil penelitian Oktariya, 2017 yang menyebutkan bahwa puree daun kelor mengandung kadar serat kasar 6,77\%, Vitamin C 3,99 mg/gram dan aktivitas antioksidan $60,05 \%$.

Tabel 2. Nilai rata-rata kadar air, kadar abu, kadar serat kasar, vitamin C dan aktivitas antioksidan puree daun kelor

\begin{tabular}{cc}
\hline Variabel uji & Jumlah \\
\hline Kadar Air (\%) & $89,31 \pm 0,16$ \\
Kadar Abu (\%) & $2,01 \pm 0,02$ \\
Kadar Serat Kasar (\%) & $6,40 \pm 0,54$ \\
Vitamin C (mg/g) & $3,27 \pm 0,002$ \\
Aktivitas Antioksidan (\%) & $55,90 \pm 1,75$ \\
\hline
\end{tabular}

\section{Hasil Analisis Siomay ayam}

\section{Kadar Air}

Hasil sidik ragam menunjukkan bahwa penambahan puree daun kelor berpengaruh sangat nyata $(\mathrm{P}<0,01)$ terhadap kadar air siomay ayam. Nilai rata-rata kadar air pada perlakuan berkisar antara 47,57\% sampai dengan 58,95\% (Tabel 3). Kadar air terendah terdapat pada perlakuan P0 dan kadar air tertinggi pada perlakuan P4. Hal tersebut menunjukkan bahwa semakin tinggi penambahan puree daun kelor maka semakin tinggi juga kadar air yang terdapat pada siomay ayam. Hal ini disebabkan karena perlakuan P4 adalah perlakuan dengan penambahan puree daun kelor tertinggi yaitu 40\%. Kadar air puree daun kelor adalah $89,32 \%$, maka kadar air yang terkandung pada puree daun kelor tersebut yang menyebabkan peningkatan kadar air pada perlakuan penambahan puree daun kelor yang semakin tinggi.

Kadar air pada siomay sudah sesuai dengan SNI yaitu maksimal 60\%. Kadar air merupakan merupakan karakteristik kimia yang sangat penting dalam bahan pangan karena dapat mempengaruhi tekstur, kenampakan dan citarasa makanan (Winarno,1996). Kadar air mempengaruhi umur simpan pada produk pangan, semakin tinggi kadar air dalam suatu produk pangan maka umur simpannya lebih pendek. Maka semakin tinggi penambahan puree daun kelor diduga dapat memperpendek umur simpan dari siomay ayam karena dapat meningkatkan kadar air pada siomay ayam. 
Tabel 3. Nilai rata-rata kadar air, kadar abu, kadar serat kasar, vitamin C dan aktivitas antioksidan siomay ayam

\begin{tabular}{cccccc}
\hline $\begin{array}{c}\text { Penambahan } \\
\text { Puree Daun } \\
\text { Kelor }\end{array}$ & Kadar Air (\%) & Kadar Abu (\%) & $\begin{array}{c}\text { Serat Kasar } \\
(\%)\end{array}$ & $\begin{array}{c}\text { Vitamin C } \\
(\mathrm{mg} / \mathrm{g})\end{array}$ & $\begin{array}{c}\text { Aktivitas } \\
\text { Antioksidan } \\
(\%)\end{array}$ \\
\hline P0 (0\%) & $47,57 \pm 1,07 \mathrm{e}$ & $1,811 \pm 0,06 \mathrm{a}$ & $0,82 \pm 0,06 \mathrm{~d}$ & $0,13 \pm 0,00 \mathrm{e}$ & $5,46 \pm 0,98 \mathrm{e}$ \\
P1 (10\%) & $50,40 \pm 0,14 \mathrm{~d}$ & $1,855 \pm 0,12 \mathrm{a}$ & $1,11 \pm 0,06 \mathrm{c}$ & $0,15 \pm 0,00 \mathrm{~d}$ & $11,10 \pm 1,58 \mathrm{~d}$ \\
P2 (20\%) & $53,20 \pm 0,85 \mathrm{c}$ & $1,906 \pm 0,03 \mathrm{a}$ & $1,56 \pm 0,14 \mathrm{~b}$ & $0,17 \pm 0,00 \mathrm{c}$ & $19,90 \pm 1,93 \mathrm{c}$ \\
P3 (30\%) & $55,91 \pm 0,94 \mathrm{~b}$ & $1,953 \pm 0,08 \mathrm{a}$ & $1,75 \pm 0,19 \mathrm{~b}$ & $0,20 \pm 0,00 \mathrm{~b}$ & $28,10 \pm 1,34 \mathrm{~b}$ \\
P4 (40\%) & $58,95 \pm 0,44 \mathrm{a}$ & $1,974 \pm 0,03 \mathrm{a}$ & $2,18 \pm 0,13 \mathrm{a}$ & $0,22 \pm 0,30 \mathrm{a}$ & $38,30 \pm 1,53 \mathrm{a}$ \\
\hline
\end{tabular}

Keterangan: Nilai rata-rata yang diikuti oleh huruf yang berbeda pada kolom yang sama menunjukan perlakuan berbeda nyata $(\mathrm{P}<0,05)$.

\section{Kadar Abu}

Hasil sidik ragam menunjukkan bahwa penambahan puree daun kelor berpengaruh tidak nyata $(\mathrm{P}>0,05)$ terhadap kadar abu siomay ayam. Nilai rata-rata kadar abu pada perlakuan berkisar antara $1,81 \%$ sampai dengan 1,97\% (Tabel 3). Hasil penelitian menunjukkan bahwa semua perlakuan tidak berbeda nyata, kemungkinan disebabkan karena kadar abu puree daun kelor tidak begitu tinggi yaitu 2,01\%. Kadar abu merupakan kadar total mineral yang terkandung pada pangan. Kadar abu siomay ayam dengan penambahan puree daun kelor sudah sesuai SNI yaitu maksimal 2,5\%.

\section{Kadar Serat Kasar}

Hasil sidik ragam menunjukkan bahwa penambahan puree daun kelor berpengaruh sangat nyata $(\mathrm{P}<0,01)$ terhadap kadar serat kasar siomay ayam. Nilai ratarata kadar serat kasar pada perlakuan berkisar antara $0,82 \%$ sampai dengan $2,18 \%$ (Tabel 3). Kadar serat kasar terendah terdapat pada perlakuan P0 dan tertinggi terdapat pada perlakuan P4. Hal tersebut menunjukkan bahwa semakin tinggi penambahan puree daun kelor maka semakin tinggi juga kadar serat kasar yang terdapat pada siomay ayam.

Puree daun kelor megandung kadar serat kasar $6,40 \%$, maka dari itu peningkatan kadar serat kasar pada siomay disebabkan oleh kandungan serat kasar puree daun kelor. Serat kasar adalah bagian dari pangan yang tidak dapat dihidrolisis oleh asam atau basa kuat. Serat kasar membantu mempercepat sisa-sisa makanan melalui saluran pencernaan untuk disekresikan keluar, dengan meningkatkan daya serap air sehingga kadar air pada feses meningkat dan mempermudah proses keluarnya feses.

\section{Kadar Vitamin C}

Hasil sidik ragam menunjukkan bahwa penambahan puree daun kelor berpengaruh sangat nyata $(\mathrm{P}<0,01)$ terhadap vitamin C siomay ayam. Nilai rata-rata 
vitamin $\mathrm{C}$ pada perlakuan berkisar antara $0,13 \mathrm{mg} / \mathrm{g}$ sampai dengan $0,22 \mathrm{mg} / \mathrm{g}$ (Tabel 3). Vitamin C terendah pada perlakuan P0 dan tertinggi terdapat pada perlakuan P4. Hal tersebut menunjukkan bahwa semakin tinggi penambahan puree daun kelor maka semakin tinggi juga vitamin $\mathrm{C}$ yang terdapat pada siomay ayam.

Puree daun kelor mengadung vitamin C $3,27 \mathrm{mg} / \mathrm{g}$, maka dari itu meningkatnya kadar vitamin $\mathrm{C}$ pada siomay disebabkan oleh kandungan vitamin $\mathrm{C}$ yang terdapat pada puree daun kelor. Vitamin $\mathrm{C}$ atau yang memiliki nama trivial asam askorbat memiliki sifat nutrasetikal karena bersifat sebagai antioksidan (Putra, 2020). Kandungan vitamin C pada siomay dapat meningkatkan aktivitas antioksidan pada siomay ayam.

\section{Aktivitas Antioksidan}

Hasil sidik ragam menunjukkan bahwa penambahan puree daun kelor berpengaruh sangat nyata $(\mathrm{P}<0,01)$ terhadap aktivitas antioksidan siomay ayam. Nilai rata-rata aktivitas antioksidan pada perlakuan berkisar antara 5,46\% sampai dengan 38,30\% (Tabel 3). Aktivitas antioksidan terendah pada perlakuan P0 dan tertinggi terdapat pada perlakuan P4. Hal tersebut menunjukkan bahwa semakin tinggi penambahan puree daun kelor maka semakin tinggi juga aktivitas antioksidan yang terdapat pada siomay ayam.

Puree daun kelor memiliki aktivitas antioksidan 55,90\%, maka dari itu peningkatan aktivitas antioksidan pada siomay disebabkan oleh aktivitas antioksidan puree daun kelor. Menurut Ikalinus et al (2015) tanaman kelor memiliki banyak kandungan senyawa aktif berupa antioksidan terutama pada bagian daunnya dengan kandungan flavonid, sterol, triterpenoid, alkaloid, saponin dan fenol. Selain itu, meningkatnya aktivitas antioksidan pada siomay ayam juga disebabkan oleh adanya kandungan vitamin C. Menurut Sukandar et al (2014) vitamin C atau asam askorbat memiliki kemampuan sebagai antioksidan dan larut dalam air. Tabel 3 menunjukkan semakin tinggi penambahan puree daun kelor maka kandungan vitamin $\mathrm{C}$ juga semakin tinggi dan semakin tinggi pula aktivitas antioksidan. Menurut Tristawati et al. (2019) vitamin $\mathrm{C}$ memiliki kolerasi yang selaras dengan dengan aktivitas antioksidan, semakin tinggi kadar vitamin $\mathrm{C}$ maka semakin tinggi juga aktivitas antioksidannya Perlakuan dengan aktivitas antioksidan tertinggi yaitu pada P4 selanjutnya dilakukan uji $\mathrm{IC}_{50}$. Menurut Molyneux (2004) bahwa $\mathrm{IC}_{50}$ merupakan konsentrasi suatu zat antioksidan yang dapat menghambat radikal bebas sebanyak 50\%. Jika nilai $\mathrm{IC}_{50}$ dibawah 50 ppm maka aktivitas antioksidannya dikategorikan sangat kuat, jika nilai IC $_{50}$ diantara 50-100 ppm maka aktivitas antioksidannya dikategorikan kuat, jika nilai $\mathrm{IC}_{50}$ 100-150 ppm berarti aktivitas antioksidannya sedang, 
jika nilai $\mathrm{IC}_{50}$ diantara $150-200$ ppm maka dikategorikan lemah dan jika nilai $\mathrm{IC}_{50}$ berada diatas 200 ppm maka aktivitas antioksidannya dikategorikan sangat lemah. Semakin kecil nilai $\mathrm{IC}_{50}$ maka semakin tinggi aktivitas antioksidan yang terkandung dalam bahan begitu juga sebaliknya semakin besar nilai $\mathrm{IC}_{50}$ maka aktivitas antioksidan semakin rendah. Nilai $\mathrm{IC}_{50}$ yang diperoleh pada perlakuan P4 yaitu sebesar 12342,28 ppm. Hal ini menunjukan bahwa antioksidan yang terkandung siomay ayam termasuk dalam katagori sangat lemah karena nilai $\mathrm{IC}_{50}>200$ ppm. Selain itu, lemahnya antioksidan pada siomay ayam diduga karena dalam proses pengolahan dengan pengukusan yang menyebabkan hilangnya kandungan antioksidan.

\section{Evaluasi Sensoris}

Sifat sensoris meliputi uji hedonik dan uji skoring. Uji hedonik dilakukan terhadap warna, aroma, tekstur, rasa dan penerimaan keseluruhan, sedangkan uji skoring dilakukan terhadap tekstur. Nilai rata-rata uji hedonik terhadap warna, aroma, tekstur, rasa, penerimaan keseluruhan dan uji skoring terhadap rasa tekstur dapat dilihat pada Tabel 4.

Tabel 4. Nilai rata-rata uji hedonik warna, aroma, rasa, penerimaan keseluruhan dan uji skoring tekstur siomay ayam

\begin{tabular}{|c|c|c|c|c|c|c|}
\hline \multirow{2}{*}{$\begin{array}{l}\text { Penambahan } \\
\text { Puree Kelor }\end{array}$} & \multicolumn{5}{|c|}{ Uji Hedonik } & \multirow{2}{*}{$\begin{array}{c}\begin{array}{c}\text { Uji } \\
\text { Skoring }\end{array} \\
\text { Tekstur }\end{array}$} \\
\hline & Warna & Aroma & Tekstur & Rasa & $\begin{array}{l}\text { Penerimaan } \\
\text { Keseluruhan }\end{array}$ & \\
\hline $\mathrm{P} 0(0 \%)$ & $3,00 \mathrm{~b}$ & $4,16 \mathrm{a}$ & $3,80 \mathrm{a}$ & $4,12 \mathrm{a}$ & $3,96 \mathrm{a}$ & $2,32 \mathrm{~b}$ \\
\hline P1 $(10 \%)$ & $3,80 \mathrm{a}$ & $3,96 \mathrm{a}$ & $3,68 \mathrm{a}$ & $4,00 \mathrm{a}$ & $3,92 \mathrm{a}$ & $2,36 \mathrm{~b}$ \\
\hline P2 $(20 \%)$ & $4,04 \mathrm{a}$ & $4,16 \mathrm{a}$ & $3,84 \mathrm{a}$ & $4,16 \mathrm{a}$ & $4,08 \mathrm{a}$ & $2,68 a b$ \\
\hline P3 $(30 \%)$ & $3,76 \mathrm{a}$ & $3,96 \mathrm{a}$ & $4,00 \mathrm{a}$ & $4,08 \mathrm{a}$ & $3,92 \mathrm{a}$ & $2,76 \mathrm{ab}$ \\
\hline $\mathrm{P} 4(40 \%)$ & $3,72 \mathrm{a}$ & $3,92 \mathrm{a}$ & $3,68 \mathrm{a}$ & $3,72 \mathrm{a}$ & $4,04 \mathrm{a}$ & $2,64 \mathrm{a}$ \\
\hline eterangan : & $\begin{array}{l}\text { Hedonik, } \\
\text { Skoring, } \\
\text { huruf ya } \\
\text { 05) }\end{array}$ & $\mathrm{xa} ; 4=\mathrm{A}$ & $\begin{array}{l}\mathrm{kaa} ; 3=\mathrm{E} \\
\text { Kenyal; } \\
\text { m yang }\end{array}$ & $\begin{array}{l}=\text { Agak } \\
\text { ak Keny }\end{array}$ & $\begin{array}{l}\text { ak Suka; } 1=\mathrm{T} \\
\text { Nilai rata-rata y } \\
\text { perlakuan bert }\end{array}$ & $\begin{array}{l}\text { ak Suka) } \\
\text { ig diikuti } \\
\text { da nyata }\end{array}$ \\
\hline
\end{tabular}

\section{Warna}

Hasil sidik ragam menunjukan bahwa perlakuan penambahan puree daun kelor berpengaruh nyata $(\mathrm{P}<0,05)$ terhadap warna (uji hedonik) siomay ayam. Tabel 4 menunjukan bahwa nilai rata-rata warna berkisar antara 3 (biasa) sampai dengan 4,04 (agak suka). Penerimaan terhadap warna terendah adalah perlakuan P0 (tanpa penambahan puree daun kelor) dan yang tertinggi adalah perlakuan P2 (penambahan puree daun kelor 20\%) dengan kriteria agak suka. Serta tidak berbeda nyata dengan perlakuan P1, P3 dan P4. Panelis agak suka dengan siomay yang ditambahkan puree daun kelor, karena puree daun kelor 
memberikan warna pada siomay ayam. Menurut Winarno (2004) bahwa warna merupakan faktor penting dalam menentukan penerimaan suatu produk oleh konsumen karena tampilan visual yang pertama kali dilihat selain itu ada beberapa faktor lainnya antara lain cita rasa, aroma dan nilai gizinya.

\section{Aroma}

Hasil sidik ragam menunjukan bahwa perlakuan penambahan puree daun kelor berpengaruh tidak nyata $(\mathrm{P}>0,05)$ terhadap aroma (uji hedonik) siomay ayam. Tabel 4 menunjukan bahwa penerimaan terhadap aroma (uji hedonik) siomay ayam adalah dengan kriteria agak suka.

\section{Tekstur}

Hasil sidik ragam menunjukan bahwa perlakuan penambahan puree daun kelor berpengaruh tidak nyata $(P>0,05)$ terhadap tekstur (uji hedonik) siomay ayam. Tabel 4 menunjukan bahwa penerimaan terhadap tekstur (uji hedonik) siomay ayam adalah dengan kriteria biasa hingga agak suka.

Hasil sidik ragam menunjukkan bahwa perlakuan penambahan puree daun kelor berpengaruh nyata $(\mathrm{P}<0,05)$ terhadap tekstur (uji skoring) siomay ayam. Tabel 4 menunjukkan bahwa nilai rata-rata uji hedonik terhadap tekstur siomay ayam berkisar antara 2,32 (kenyal) sampai dengan 2,76 (sangat kenyal). Tekstur merupakan salah satu faktor penting dalam penlaian suatu produk terutama siomay yang biasanya memiliki tekstur kenyal.

\section{Rasa}

Hasil sidik ragam menunjukan bahwa perlakuan penambahan puree daun kelor berpengaruh tidak nyata $(\mathrm{P}>0,05)$ terhadap rasa (uji hedonik) siomay ayam. Tabel 4 menunjukan bahwa penerimaan terhadap rasa (uji hedonik) siomay ayam adalah dengan kriteria biasa hingga agak suka. Hal ini menunjukan bahwa panelis dapat menerima rasa siomay ayam dan tingkat kepekaan indera pengecap panelis yang berbeda juga mempengaruhi hasil uji hedonik terhadap rasa siomay ayam. Rasa merupakan salah satu faktor terpenting dalam penilaian suatu produk. Menurut Meilgaard et al. (2000) bahwa penilaian rasa dilakukan oleh indera pengecap rasa manusia ketika mengkonsumsi makanan atau minuman.

\section{Penerimaan Keseluruhan}

Hasil sidik ragam menunjukan bahwa perlakuan penambahan puree daun kelor berpengaruh tidak nyata $(\mathrm{P}>0,05)$ terhadap penerimaan keseluruhan (uji hedonik) siomay ayam. Tabel 4 menunjukan bahwa penerimaan terhadap penerimaan keseluruhan (uji hedonik) siomay ayam adalah dengan kriteria biasa hingga agak suka. Penerimaan keseluruhan merupakan penilaian secara menyeluruh terhadap suatu produk yang meliputi warna, aroma, tekstur dan rasa. Hal ini menunjukan bahwa panelis 
dapat menerima siomay ayam dari segi warna, aroma, tekstur dan rasa.

\section{KESIMPULAN}

\section{Kesimpulan}

Penambahan puree daun kelor berpengaruh sangat nyata terhadap kadar air, kadar serat kasar, vitamin $\mathrm{C}$, aktivitas antioksidan, berpengaruh nyata terhadap kadar abu, warna (uji hedonik) dan tekstur (uji skoring). Namun berpengaruh tidak nyata terhadap tekstur, aroma, rasa dan penerimaan keseluruhan (uji hedonik). Hal tersebut menunjukkan penambahan puree daun kelor dapat meningkatkan kandungan gizi siomay ayam meliputi kadar serat kasar, Vitamin C dan antioksidan namun tidak mempengaruhi sifat sensoris siomay ayam meliputi tekstur, aroma, rasa dan penerimaan keseluruhan.

Perlakuan terbaik pada penelitian ini yaitu siomay ayam dengan penambahan puree daun kelor $40 \%$ yaitu: kadar air 58,95\%, kadar abu 1,97\%, kadar serat kasar 2,18\%, vitamin C $0,22 \mathrm{mg} / \mathrm{g}$ dan aktivitas antioksidan $38,30 \%$ dengan nilai $\mathrm{IC}_{50}$ 12342,28 ppm, tekstur sangat kenyal dan agak suka, warna, aroma, rasa dan penerimaan keseluruhan agak suka.

\section{Saran}

1. Pembuatan siomay ayam dengan penambahan daun kelor dapat dilakukan dengan penambahan puree daun kelor $40 \%$.

2. Perlu dilakukan penelitian lebih lanjut terkait umur simpan siomay ayam.

\section{DAFTAR PUSTAKA}

AOAC. 1995. Official Methods of Analysis of Association of Official Analytical Chemist. AOAC International. Virginia USA.

Ariyani, E.M. 2015. Formulasi Rumput Laut (Glacilaria Sp) Dalam Pembuatan Siomay Sebagai Pangan Fungsional Tinggi Iodium dan Serat. Skripsi. Tidak Dipublikasikan. Fakultas Teknologi Pertanian. IPB, Bogor.

Asih, W.R., Kuswanto dan Widanti. 2017. Penambahan puree daun kelor (Moringa oleifera) dan puree pisang ambon untuk formula mpasi (makanan pendamping asi). Jurnal Teknologi dan Industri Pangan 3(1): 10-17.

Foild N, Makkar HPS \& Becker. 2007. The Potential of Moringa oleifera for Agricultural and Industrial Uses. Mesir; Daar Es Salaam.

Gomez, K. A. dan A. A. Gomez. 1995. Prosedur Statistik Untuk Penelitian Pertanian. UI Press. Jakarta.

Gopalakrishnan, L., K, Doriya,.and Kumar, D.S. 2016. Moringa oleifera: A review on nutritive importance and its medicinal application. Journal Food Science and Human Wellness.

Ikalinus, R. K, W, Sri., dan N, L, E, Setiasih. 2015. Skrining fitokimia ekstrak etanol kulit batang kelor (Moringa oleifera). Indonesia Medicus Veterinus. Bali. 4( 1 ): $71-79$.

Kasolo, J.N., Bimeya, G.S., Ojok, L., Ochieng, J., Okwal-okeng, J.W. 2010. Phytochemicals and uses of Moringa oleifera leaves in ugandan rural communities. Journal of Medical Plant Research. Vol. 4(9): 753-757.

Meilgaard, M. Civille G,V., Carr B,T. 2000. Sensory Evaluation Techniques. CRC Press, Boca Raton.

Misra, A., Srivastava, S., \& Srivastava, M. 2014. Evaluation of anti diarrheal potential of Moringa oleifera (Lam.) leaves. Journal of Pharmacognosy and Phytochemistry, 2(5), 43-46.

Molyneux, P. 2004. The use of the stable free radical diphenylpicryllhydrazyl 
(DPPH) for estimating antioxidant activity. Journal of Science Technology, 26(2), 211-219.

Novelia, Y., T.A Wulandari. 2016. Perencanaan Usaha Siomay Ayam dan Siomay Ayam Jagung. Tugas Perencanaan Unit Pengolahan Pangan. Universitas Katolik Widya Mandala. Surabaya.

Oktaria, U. 2017. Analisis Kandungan Vitamin C Dalam Daun Kelor (Studi di Wilayah Kabupaten Jombang. Sekolah Tinggi Ilmu Kesehatan Insan Cendekia Medika. Jombang.

Soekarto, S.T. 1985. Penilaian Organoleptik Untuk Industri Pangan dan Pertanian. Bharata Karya Aksara. Jakarta.

Sompong, R., S. S. Ehn, G. L. Martin dan E. Berghofer. 2011. Physichemical and antioxidative properties of red and black rice varieties from thailand, china, and sri lanka. Food Chemistry 124: $132-140$.

Sudarmadji, S. B. Haryono dan Suhardi. 1997. Prosedur Analisa Untuk Bahan Makanan dan Pertanian. Liberty. Yogyakarta.
Sukandar, D., Muawanah, A., Adawiah. 2014. Aktivitas Antioksidan dan Kandungan Bioaktif Sai Buah Namnam. Jurnal Kimia Valensi: Jurnal Penelitian dan Pengembangan Ilmu Kimia, 1(2) 130-136.

Trisnawati, I., W. Hersoelistyorini dan Nurhidajah. 2019. Tingkat kekeruhan, kadar vitamin c, dan aktivitas antioksidan infused water lemon dengan variasi suhu dan waktu perebusan Jurnal Pangan dan Gizi. 9(1): 27-38.

Verma, A.R., Vijayakumar, M., Mathela, C.S., Rao, C.V., 2009. In vitro and in vivo antioxidant properties of different fractions of Moringa oleifera leaves. Food Chem. Toxicol. 47, 2196- 2201.

Vuong, Q.V., S. Hirun dan C.J. Scarlett. 2014. Physicochemical composition, antioxidant and anti-proliferative capacity of a lilly pilly (Syzygium paniculatum) extract. Herbal Medicine. 4:134-140.

Winarno, F.G., 1997. Kimia Pangan dan Gizi. PT Gramedia Pustaka Utama. Jakarta. 